Article

\title{
Narrating a Valley in Max Frisch's Der Mensch erscheint im Holozän: Material Agency, Rain, and the Geologic Past
}

\author{
Kiley M. Kost
}

\author{
Department of German and Russian, Carleton College, Northfield, IL 55057, USA; kkost@carleton.edu
}

\begin{abstract}
The complex narrative composition of image and text in Max Frisch's Der Mensch erscheint im Holozän discloses entanglements between humans and nonhuman entities that impact the narrative and that demand careful consideration. The story depicts the aging protagonist's struggle with memory loss and his careful examination of the valley's mountain formations in fear of a landslide. In this analysis, I show that both of these threats can be read as entangled with nonhuman agents. By focusing on the material dimension of the text, two central and related shifts occur: the background element of rain becomes foregrounded in the narrative, and the natural formations of the valley that are assumed to be static are revealed to be dynamic. These shifts lead to an interpretation of Frisch's text focused on the impacts of rain and the temporal scale of the text's geologic dimension. Approaching the text through the lens of material ecocriticism unveils the multiple agencies at play, decenters the human, and illustrates the embodied experience of climate change.
\end{abstract}

Keywords: material ecocriticism; rain; geology; scale; Max Frisch; Der Mensch erscheint im Holozän

check for updates

Citation: Kost, Kiley M.. 2021. Narrating a Valley in Max Frisch's Der Mensch erscheint im Holozän: Material Agency, Rain, and the Geologic Past. Humanities 10: 43. https://doi.org/10.3390/h10010043

Received: 1 December 2020

Accepted: 24 December 2020

Published: 4 March 2021

Publisher's Note: MDPI stays neutral with regard to jurisdictional claims in published maps and institutional affiliations.

Copyright: (c) 2021 by the author. Licensee MDPI, Basel, Switzerland. This article is an open access article distributed under the terms and conditions of the Creative Commons Attribution (CC BY) license (https:// creativecommons.org/licenses/by/ $4.0 /)$.

\section{1. "Draußen regnet es"}

When Max Frisch was living in Berzona, a small village near Lake Maggiore in the Swiss canton of Ticino, his friend and editor Uwe Johnson gifted him a book about the region: Der Lago Maggiore und seine Täler (Lake Maggiore and its Valleys). Frisch wrote to Johnson in 1972 thanking him for the gift and noted that the book might have inspired an idea: "Es kann sein, daß Sie mir mit dem Geschenk, Ihrem kuriosen Fund in einem Antiquariat, etwas eingebrockt haben, etwas wie eine Erzählung" (Frisch and Johnson 1999, p. 49-50, "It is possible that with your present, your odd find in an antiquarian bookshop, you have landed me with something resembling a story"). Seven years later, in 1979, clippings from this book and a number of others would appear reprinted alongside Frisch's narrative text in the resulting book Der Mensch erscheint im Holozän: Eine Erzählung (Man in the Holocene: A Story). As the evocative title suggests, one of the themes Frisch explores in the narrative is the origin of human life in the geologic past. Frisch includes detailed information about the formation of the alpine region, looking into the deep past to illustrate how powerful glaciers sculpted mountain peaks and land formations. At the same time, Frisch also focuses on more discernable transformations in the landscape that are brought on by sudden severe weather, telling both a familiar story focused on the protagonist Herr Geiser as well as a story about nonhuman, material elements.

A glimmer of this material dimension is present in the same letter Frisch wrote to Johnson. He continues, "Es sind wieder Wochen her, ich bin immer neugieriger geworden und habe noch einiges dazu gefunden. Jetzt müßte es nur noch gelingen, nämlich: ein Tal zu erzählen" (Frisch and Johnson 1999, p. 50, "Once again it has been weeks and I have become more curious, and have found quite a few more things. Now it is just a matter of succeeding, that is: succeeding in narrating a valley"). Frisch's curious goal here, "ein Tal zu erzählen" ("to narrate a valley"), points to a central tension in the resulting text: background elements presumed to be static come to life when considered as key elements of the narrative. To read Frisch's Der Mensch erscheint im Holozän, therefore, is to 
repeatedly be made aware of forces and agencies of matter that are usually dismissed as inconsequential background elements, including the mountainous setting of the story and the rain that seems to fall endlessly.

It is in fact this rain that creates the very conditions of the 1979 narrative. Days of heavy rain and storms have isolated the 73-year-old protagonist Herr Geiser in a small valley town in Ticino, Switzerland; roads to and from the town are closed, mail cannot be delivered, and intermittent power outages restrict television news. The Swiss author's narrative follows the elderly Herr Geiser as he grapples with multiple threats, including damage to his surroundings caused by the severe weather and his deteriorating health that results in a stroke. The rain and storms that have isolated the protagonist indoors have the potential to cause a landslide that would bury Herr Geiser and the village, a disaster with historical precedent noted in history books of the region. In order to distract himself from the threat of natural disaster, Herr Geiser engages in several activities to pass the time. He attempts to build a pagoda out of crispbread, categorizes the different types of thunder he hears, and takes an inventory of provisions in the house. Then he begins to look up information in his extensive non-fiction collection, clipping passages from the books and taping them to his wall. Along with handwritten notes, these snippets are printed in the text and the reader must reconstruct Herr Geiser's train of thought by following both the prose narration and the images scattered throughout the text. As the narrative progresses, the clippings reveal that Herr Geiser is actually struggling with memory loss and relying on the notes as an information database. Troubled by his isolation and lacking the cognitive functions that should have stopped him, Herr Geiser then attempts to hike out of the valley, but ultimately turns around. When he returns home from the hike with several injuries and numbness on his left side, an encyclopedia clipping about strokes confirms the reader's suspicion.

In the mere 150 pages that form Der Mensch erscheint im Holozän, Frisch touches on an expansive range of topics including aging, memory, memory loss, isolation, prehistory, epistemology, and disaster. Because they are ubiquitous and familiar, rain and other nonhuman agents have been overlooked alongside such compelling and conspicuous topics, but rain and other nonhuman forces are entangled with each of these motifs in the text. Indeed, Frisch had tentatively titled his book both Regen (rain) and Klima (climate) (Kilcher 2011, p. 114). Using the framework of material ecocriticism to interpret the text, these "background" elements become discernable as pivotal parts of the narrative, and Frisch's aim of "narrating a valley" can be understood as telling a story of nonhuman agency. By focusing on the text's material dimension, two central and related shifts occur: the background element of rain becomes foregrounded, and the natural formations of the valley, including glaciers, that are assumed to be static are revealed to be dynamic. With this turn, Frisch articulates the agentic capacity of the nonhuman and decenters "der Mensch" by positioning humans as part of a "field of distributed agency" shared with "countless other actors," as Iovino and Oppermann write (Iovino and Oppermann 2012, p. 451).

The geologic scale of the valley and glaciers makes the shift more striking, aligning with Timothy Clark's notion of "scalar literacy" that draws attention to the importance of scale and "takes up the challenge of giving sensuous representation of scales in space or time that greatly exceed immediate perception" (Clark 2020, p. 39). ${ }^{1}$ The main material elements that I consider - rain, rock faces, and glaciers-inhabit distinct spatial and temporal scales, and it is only through attentiveness to their disparate scales that they can be read as narrative agents in the text. Moreover, Frisch's collage of text and image introduces elements of non-fiction into the fictional narrative and it is partially through the non-fiction elements that Frisch articulates nonhuman agency. In the final section of this article, I extend my consideration of the text's material dimension to the book itself to explore the significance of its form.

1 Clark arrives at his concept of "scalar literacy" by way of Derek Woods's "Scale Critique of the Anthropocene" (Woods 2014). 
Contemporary analyses of Der Mensch erscheint im Holozän have been largely focused on its environmental aspects, especially since the Anthropocene has become a topic of interest in the humanities, but these interpretations have been restricted to traditional scholarly approaches focused on themes and metaphors connected to the environment. Frisch's focus on the nonhuman environment demands a different approach that accounts for material agency. Despite the alpine setting that might conjure imagery of the Romantic sublime, Frisch depicts nature neither as an aesthetic object for visual consumption nor as a static backdrop upon which human lives unfold. Instead, he emphasizes the dynamic interaction of the protagonist with his surroundings by decentering the human and positioning the nonhuman environment as a significant agent in the narrative. As the effects of climate change continue to go on unmitigated and the frequency and intensity of storms increase, Der Mensch erscheint im Holozän unveils the impact of these nonhuman forces and exposes the embodied experience of climate change. Indeed, Frisch offers detailed descriptions of natural disasters, rising sea levels, and geologic timescales, albeit separate from the contemporary awareness of anthropogenic climate change.

The environmental changes and catastrophes depicted in Der Mensch erscheint im Holozän have previously been read as metaphors for Herr Geiser's health or the fate of humans in general by scholars of German ecocriticism. Dürbeck (2017), for example, views the rain as one of many examples of catastrophe in the text, writing that "[t]he rainfall and the threat to humans serve as an allegory not only for human physical decline but also for the vision of an unstable natural world, where natural disaster and even the extinction of mankind loom everywhere" (Dürbeck 2017, p. 335). Similarly, Malkmus (2017) interprets Der Mensch erscheint im Holozän as emblematic of the changing understanding of humans' place in the world; as anthropogenic environmental changes shift on a global scale, so too do the conceptual categories used to understand one's relation to the nonhuman world (Malkmus 2017). ${ }^{2}$ Along these lines, Völker (2016) reads the narrative structure of the text as inextricably connected to the geologic time scales and depicting "temporal forms of deceleration, slowness, and standstill that are realized through the use of montage, parataxis, and enumeration," but does not figure rain into his analysis (Völker 2016, p. 10). Silber (2014) and Röthinger (2015) focus on the parallels between Herr Geiser's deteriorating condition and the recurring motifs of erosions and landslides in the text.

Attanucci (2016) examines the role of geology in Der Mensch erscheint im Holozän, noting that the field, with its concern with eras and ends, is a fitting topic for an aging person. His arguments follow Braungart (2007), who shows how the geologic dimension of the text helps to create a transhuman perspective. This perspective extends beyond Herr Geiser's single experience by means of the insights into human history and geology offered by the clippings in the text. However, both Braungart (2007) and Attanucci (2016) only consider how geology functions in the text thematically and they do not consider how the material realm is an integral part of the narrative. By combining distinct temporal and material scales, Frisch reveals nonhuman elements such as rain and glaciers to be dynamic entities and significant narrative elements in the text.

\section{Rain and the Brain: "Ein Weg ist ein Weg auch im Nebel"}

The sound of rain on metal and nonstop thunder, the ceaseless gurgling around the house, and the eerie silence of roads closed to traffic. Herr Geiser's experience of the storm is all-encompassing. Yet, beyond the sensory experience of sheltering from severe weather, the storm has a profound, material impact on his surroundings and his own body. Herr Geiser's body is put at risk by the rain as flooded hiking paths compound his cognitive issues and changing pressure systems disrupt his circulatory system, ultimately leading

2 Elsewhere Malkmus argues that the title of the book is scientifically incorrect because humans' evolutionary ancestors first appeared in an earlier geologic epoch-the Pleistocene, not the Holocene (Malkmus 2015, p. 189). While Malkmus uses this error to claim that "der Mensch" that interests Frisch is a specific and symbolic version of humans that have brought about the environmental degradation familiar today, it must be noted that Frisch is not concerned with scientific accuracy in the book. Rather, the geologic dimension evoked in the title sharply repositions the scale and focus of the narrative. 
to his stroke. When he attempts to escape his isolation by hiking out of the valley, he encounters unfamiliar terrain that differs from his memory and the maps he uses to guide his way. The rain literally transforms the landscape, and these altered landscapes directly impact Herr Geiser by posing physical and cognitive challenges that arise when trying to navigate a newly unfamiliar route.

During the few moments when the rain stops, it is replaced by the sound of rushing water because the increased rainfall from the storm creates new streams and causes small creeks in the valley to flow more forcefully. Descriptions of these newly formed streams emphasize the recent changes in the landscape and the inescapable presence of the water: “...es müssen Bäche sein überall, viele Bäche, die es sonst nicht gibt. Ein stetes Rauschen aus dem ganzen Tal” (Frisch 1979, p. 17, “There must be streams everywhere, streams that normally do not exist. A constant rushing sound throughout the valley;" English translations from Geoffrey Skelton (Frisch 1980)). The sudden presence of numerous currents of water unsettles Herr Geiser as he faces difficulty judging the size and current of the streams and whether he will be able to cross them. Moreover, because the streams are the result of the sudden increase in rain, they are not marked on his map, which leads Herr Geiser to question his position. One particular example illustrates the issues in navigation he faces in light of the rain: "Ein Bach ohne Brücke, eigentlich kein Bach, sondern ein Gewässer, das es nur nach langen Unwettern gibt und das auf der Karte nicht verzeichnet ist, ein breites Gewässer über Geröll ... " (Frisch 1979, p. 94-95, “An unbridged stream, not a proper stream but a stretch of flowing water that is just the result of persistent rain and is not marked on the map, water flowing over debris"). The description of the stream as a "Gewässer," an amorphous body of water, discloses the origins of the water in the storm; a "real" stream would be marked on the map and would have a bridge. Nonetheless, Herr Geiser attempts to cross this body of water, which takes him around half an hour. He carefully charts his path using "zuverlässige Steine" ("stones he could trust") that will not move when stepped on. He makes it across, but slips on one stone and ends up with a shoe full of water. Because these newly formed streams do not match up with the map Herr Geiser uses to guide his trek, they compound his cognitive confusion. The divide between Herr Geiser's precarious mental state and the ostensible security of the map grows throughout the narrative and his hike. Due to his disorientation, he ends up backtracking and taking a steeper path that is much more difficult for the elderly Herr Geiser. As a result, he suffers numerous injuries and aches that immediately precede his stroke, which can be read as an example of how his body is impacted by the storm.

In his essay "When it Rains," Duckert (2014) explores the interpretive possibilities opened when rain is taken as an agent or force in its own right. Following Bennett (2010) vibrant materialism and Latour (2005) actor-network theory, Duckert asks what happens when the it of "it is raining" is considered seriously and which new relationships and embodiments are brought into being when it rains. This is particularly important for understanding Frisch because the rain and storms participate in the narrative through the entanglements between humans and nonhuman that they engender. Duckert argues that rain "precipitates in the literal sense," by causing things to happen and creating entanglements (Duckert 2014, p. 116; original emphasis). In an astute observation, Duckert writes that "[t]he agency of rain is typically hidden until it falls irregularly or causes something to fail" and in Der Mensch erscheint im Holozän, rain's agency becomes salient as it causes the landscape to change and, as I will show, leads to Herr Geiser's stroke (Duckert 2014, p. 114).

As Duckert eloquently describes, "rain is arguably the most attentive to issues of exposure; rain captures and connects bodies at their most open and porous, and its piercing quality stresses the real violence of bodily penetrability" (Duckert 2017, p. 167). Rain, fog, and thunder encircle Herr Geiser, absorbing his modes of perception. He is thoroughly engulfed by weather as he categorizes the types of thunder based on the sound of the storm that then resonates throughout the narrative. At one point, he turns to the rain to keep track of time, exemplifying the connection between time and weather and mirroring the villager's outcries of “CHE TEMPO, CHE TEMPO!” (Frisch 1979, p. 73). Time and weather, 
both tempo in Italian, become increasingly connected, which Völker reads as a central part of the disruption of human time created by the narrative structure and thematic focus of geologic time.

A logbook of the different types of rain throughout the day shows how Herr Geiser attempts to pass the time by observing the varying types and state of rain:

Sonntag:

10.00

Regen wie Spinnweben über dem Gelände.

10.40

Regen als Perlen an der Scheibe.

[... ]

11.50

kein Regen.

13.00

Regen, der nicht zu sehen ist, man spürt ihn bloß auf der Haut, wenn man die Hand aus dem Fenster streckt.

15.10

Regen als Zischen im Laub der Kastanie.

15.20

Regen wie Spinnweben

[...]

23.00

Regen als Glitzern im Schein der Taschenlampe. (Frisch 1979, 54-55, "Sunday:/10:00 A.M./Rain as cobwebs over the grounds./10:40 A.M./Rain as pearls on the windowpane./[ . . ] 11:50 A.M./No rain./1:00 P.M./Rain invisible to the eye, but, stretching a hand out of the window, one feels it on one's skin./3:10 P.M./ Rain as a hissing sound in the leaves of the chestnut trees./3:20 P.M./Rain like cobwebs./[ ... ] 11:00 P.M./Rain as a glittering in the beam of a flashlight.")

His account of the rain is one of many such lists and logs of weather observations, but this passage in particular stands out because it presents a compelling material-temporal narrative of the "it" in "it rains." In the form of a logbook and connected to the time on the clock, the presence or absence of the rain is embedded in a temporal relationship, creating a narrative made legible to the reader by processes of human perception. Herr Geiser registers the relations through the sights, sounds, and feeling of rain, distinguishing between them and thereby registering the passing of time. At 13.00 in the log, when he cannot see whether it is raining, he sticks his hand out the window to feel it, entangling his body in a relationship with the rain. Each description of the rain epitomizes Latour's definition of how objects must be included as actants in social relationships in order to fully understand networks of connections. Of the social, Latour writes "[i]t is an association between entities which are in no way recognizable as being social in the ordinary manner, except during the brief moment when they are reshuffled together" (Latour 2005, p. 65; original emphasis). Indeed, Duckert connects Latour's concept of the social to rain in particular, writing in his analysis that rain "reminds us that there are only things in relations and as relations, beings in cascade with everywhere to fall" (Duckert 2014, p. 120; original emphasis). In Herr Geiser's rain log, there is an assemblage of relations between the rain, the window pane, Herr Geiser's body, the leaves of the chestnut tree, and the light beam of a flashlight, among many others. What renders this passage both cryptic and profound is that, as a distinct sequence of events over a duration of time, Frisch presents a narrative of the rain that places this background element as a central component of the narrative. 
Feeling the rain on one's skin is a palpable instance of how precipitation impacts the body. Paying careful attention to the impact of weather on living bodies resonates with Stacy Alaimo's theory of trans-corporeality that traces how the body is entangled with material flows. In her monograph Bodily Natures: Science, Environment, and the Material Self, Alaimo (2010) describes that trans-corporeality "not only traces how various substances travel across and within the human body but how they do things-often unwelcome or unexpected things" (Alaimo 2010, p. 146; original emphasis). Approaching Frisch's narrative attuned to trans-corporeality, Herr Geiser's stroke can be traced to the rain and the changes in the atmosphere brought about by the storm, yet this connection is buried in the clippings sprinkled throughout the book. By not explicitly identifying the connection between the storm and Herr Geiser's stroke in his prose narration, Frisch reveals the subtle influence of a material agent-the rainstorm — with a narrative technique that unfolds through material texts-the clippings that impose on the text.

An encyclopedia clipping detailing the impact of storms on humans and animals is crucial for unpacking how Herr Geiser is influenced by the rainstorm. The first line of the clipping explains the direct impact of weather on the nervous system of humans and animals: "Die Lebensvorgänge im menschl. und tier. Organismus werden durch [Gewitter] insofern beeinflußt, als die Labilisierung der Wetterlage ( $\rightarrow$ Wetter) eine erhöhte Erregbarkeit des vegetativen Nervensystems bewirkt" (Frisch 1979, p. 114, "The vital functions of human beings and animals are influenced by thunderstorms to the extent that unstable weather conditions (see Weather) exacerbate the responses of the sympathetic nervous system"). The vegetative nervous system, now known as the autonomic nervous system, regulates the organs of the body and keeps them functioning. Storms, the entry continues, can lead to changes in blood circulation and even blood clots, "... auch Embolien können sich an Tagen mit [Gewitter] häufen" (Frisch 1979, p. 114, "embolisms can occur more frequently on days when the atmosphere is thundery"). Embolisms, blot clots caused by a particle blocking a blood vessel, are also connected to strokes. This fact becomes critical in connection with the last clipping in the book-an encyclopedia entry on strokes-and reveals how Herr Geiser's body is entangled with weather systems as the changes in pressure impact his vital functions. The final entry, titled "Schlaganfall, Gehirnschlag, Hirnschlag," describes how strokes occur in the body and, most tellingly, also explains how blood clots can produce similar effects: "Auch plötzliche Verstopfungen von Blutadern (Embolie) können ähnliche Symptome hervorrufen" (Frisch 1979, p. 141; original emphasis, "Another cause of the loss of brain function is the blocking of a cerebral blood vessel, preventing blood from reaching the brain (embolism)"). Connecting the two clippings that describe embolisms offers a different diagnosis for Herr Geiser-that the changing atmospheric pressure that accompanied the storm and rain led to an embolism and stroke-like symptoms. Added to these details in the encyclopedia entry on "Gewitter" is the description of how storms can also lead to significant changes in the mental and emotional state of humans and animals: "Im allgemeinen scheint bei Mensch und Tier der seelische Eindruck des G. (Erweckung von Angst oder einer interessanten Spannung) den physischen Einfluß auf den Organismus (Verursachung oder Verschlechterung einer Krankheit) wesentlich zu überwiegen" (Frisch 1979, p. 114, "As a general rule it can be stated that, in both human beings and animals, the psychological effects of a thunderstorm (feelings of anxiety of tension) tend to outweigh the psychical ones (the occasioning or aggravation of an illness)"). The psychological effects outlined here can clearly been seen in Herr Geiser as he struggles to cope with his isolation and instead attempts a dangerous hike.

The physiological effects of a stroke detailed in the encyclopedia entry align Herr Geiser's experience after the hike and his classic stroke symptoms: "Es ist das Augenlid links. Wenn man das Augenlid mit dem Finger berührt, so fühlt das Augenlid überhaupt nichts" (Frisch 1979, p. 121, "It is his left eyelid. No pain. When one puts a finger on it, there is no feeling at all in the eyelid"). As fitting with the distant narrator of the text, the effects of the stroke are described with impersonal language. The third-person German pronoun "man" and the lack of possessive pronouns ("das Augenlid links") likens Herr 
Geiser to the detached and impersonal human diagram in the encyclopedia entry. Further anatomical indications of his stroke are similarly distant, describing that "[d]as Augenlid, links, bleibt gelähmt" and "[e]s bleibt der Druck über der linken Schläfe" (Frisch 1979, p. 124, "The eyelid, the left one, is still numb" and "the tight feeling above his left temple persists"). In these and other examples, it is clear that the left side of Herr Geiser's body is impacted, which aligns with the encyclopedia entry that states "[d]ie Lähmungen betreffen meist nur eine Körperhälfte (Hemiplegie)" (Frisch 1979, p. 141, "The paralysis usually affects only one part of the body (hemiplegia)"). Frisch weaves this anatomical perspective throughout the text by focusing on Herr Geiser's biological functions at the material level. The narrator depicts Herr Geiser's awareness of his body and vascular system, noting that his exhaustion is "fast ein Wohlgefühl in den Adern" (Frisch 1979, p. 108, "almost a pleasant feeling in one's veins"). Feeling his pulse-the pumping of his blood—and the "Herzklopflen" offers him reassurance of his vitality, but also lingers as an unseen threat that this fundamental bodily system could cease functioning if he continues his hike.

The image that accompanies the encyclopedia entry on strokes strips the human down to bodily components, showing only the outline of the human form and the brain, spinal cord, and major arteries on the right side of the body. This clinical representation resembles several other clippings throughout the book that depict skeletons of dinosaurs and amphibians, evoking the vast scale of evolution and placing the human alongside other organisms that have gone extinct. The focus on the human spinal cord in the image creates a connection to the reptilian brain: the cerebellum and brainstem. These vital components control balance, voluntary movements, motor functions, and cognitive power, which are all critical components of being (un)able to navigate difficult terrain and hike out the valley. ${ }^{3}$ One clipping in particular shows a striking contrast: an image compares the size of a Spinosaurus skeleton to a human skeleton. Next to the dinosaur skeleton that is nearly nine meters long, the human skeleton appears tiny, visually emphasizing the insignificance of the human. It also recalls earlier imagery of a skeleton in the text when Herr Geiser rummages through his junk drawer in search of his passport and uncovers, among many other things, "ein verjährtes Röntgen-Bild von seiner Wirbelsäule, seinen grauen Rippen, seinen weißen Hüftknochen ... " (Frisch 1979, p. 76-77, "an out-of-date X-ray picture of his spine, his gray ribs, his white bones"). Although the x-ray image is only described, it reduces Herr Geiser to the bone and creates a material connection to the other skeletal figures in the text. Frisch's focus on the bones of the x-ray and skeleton reveals the form of the human as inorganic matter and suggests that, like the Spinosaurus, humans will one day only exist as fossils, their history preserved in a material form. The minerality of bones establishes a connection to the very material of the surrounding mountains, which Frisch reinforces by describing the mountains in the valley as "knochenbleich, nicht grau oder schwarz, sondern knochenbleich" (Frisch 1979, p. 127-128, "the rock is the color of bone, not gray or black but pale like a bone").

A handwritten note that immediately follows the encyclopedia entry on memory loss connects the brain with the aqueous element of rain. It reads, "Die Zellen, die den menschlichen Körper bilden, inbegriffen das Hirn, bestehen mehrheitlich aus Wasser" (Frisch 1979, p. 53, "The cells making up the human body, including the brain, consist mainly of water"). Detached from emotions or history, the focus on the cellular makeup of the body presents an objective description of "der Mensch," flattening human exceptionalism and instead depicting the human body on a material and elemental level. The focus on the brain in particular further strengthens the connections between rain, weather, and pressure systems. Alongside of the geologic scale present throughout the text that I will explore next, Frisch, at times, zooms in on the body at a cellular level, exposing how the anatomic makeup of humans is based on the same fundamental elements as is found in the surrounding environment and how humans are, therefore, exposed to the same forces of nature that impact the environment. In contrast to scholars who see Herr Geiser's

The focus on the reptilian brain and its functions connect to the narrative's focus on evolution. 
stroke and deterioration as a metaphor, I contend that decentering the human perspective to include other agencies produces a distinct narrative in which rain emerges as central agent. In order to fully grasp the role of rain in the text, the reader must piece together the narrative from the clippings and Frisch's choppy prose in the collage of image and text.

\section{Geologic Scale: "Das ist alles lange her"}

The extreme and sudden weather described above unsettles Herr Geiser and alters his surroundings, providing one example of nonhuman agency. The focus on rain also illustrates a central finding of Frisch's narrative and of geology - that small changes over time can add up to have a much larger effect. Frisch's focus on geologic time shifts the temporal scale of the text to reveal dynamic stories of nonhuman agencies with origins in the deep past. Considering the nonhuman elements present in Der Mensch erscheint im Holozän through the interpretive framework of material ecocriticism reveals how such nonhuman entities propel the narrative. Scholars working in material ecocriticism draw from theories of new materialism to explore how the agency of matter produces meaning through various interactions or assemblages. Iovino and Oppermann (2012), for example, regard matter as perpetually in a state of becoming, emerging and making meaning from what Barad (2007) calls "intra-actions." Iovino and Oppermann's framing of the agentic capacity of matter sheds light on the complex processes that make up the world, and the meaning produced by each instance of entanglement of people, things, and discourse.

The scale of geologic time permeates the narrative through Herr Geiser's focus on the geologic formations around him and his acknowledgement of the multitude of forces that make up the landscape. In part, his search for origins is driven by his memory loss and he attempts to reconstruct knowledge he once had. However, it is his fear of a landslide or other natural disaster that leads him to search for the specific geologic knowledge he has forgotten. Following clippings that detail the history of flooding in the region, the narrator remarks on Herr Geiser's lapsed knowledge of natural processes, stating "Wie Flut und Ebbe entstehen, wie Vulkane, wie Gebirge usw., hat Herr Geiser einmal gewußt" (Frisch 1979, p. 27, "Geiser knew at one time what caused tides, just as he knew about volcanoes, mountain ranges, etc."). ${ }^{4}$ From a material ecocriticism perspective, what stands out here is the verb entstehen, which means to come into existence or to develop. This formulation is a recognition of nonhuman nature as a process, as an entity made up of a number of forces. Moreover, the present tense form of the verb entstehen signals that these processes are still at work in the present. Change that produces mountain ranges and volcanoes is only comprehensible on the massive scale of geologic time that Frisch includes.

Herr Geiser's concern with cracks and fissures in the rock face mirror cracks in his cognition and memory, blurring the boundaries between the time frame of Herr Geiser's individual life and deep time. Avalanches and landslides fittingly illustrate the potential for Herr Geiser's health to take a sudden turn toward collapse. Looking for signs of potential weak spots around him illustrates how small actions transform into larger, more threatening ones: "Bedenklicher als der Einsturz einer Trockenmauer wäre ein Riß durchs Gelände, ein vorerst schmaler Riß, handbreit, aber ein Riß_"' (Frisch 1979, p. 45, "More serious than the collapse of a dry-stone wall would be a crack across the grounds, narrow at first, no broader than a hand, but a crack-"). He is more concerned about a fissure in the rock face as sign of potential destruction than the collapse of retaining wall. The destruction of the wall would likely cause significant damage, but Geiser intuitively fears destruction on a larger scale. Clippings from history books that appear in the text reinforce his fear of rockslides as the provide evidence of previous landslides, including one that buried houses and their occupants "ganz unerwartet" (Frisch 1979, p. 22, "without warning," literally "completely unexpectedly").

A parenthetical remark immediately follows, explaining why a single fissure is so meaningful, "(So fangen Erdrutsche an, wobei solche Risse lautlos entstehen und sich

4 The high and low tides mentioned here evoke another temporal dimension of 24-hour times cycles. 
Wochen lang nicht erweitern oder kaum, bis plötzlich, wenn man nichts erwartet, der ganze Hang unterhalb des Risses rutscht und auch Wälder mit sich reißt und alles, was nicht Grundfels ist)" (Frisch 1979, p. 45, "(That is the way landslides begin, cracks appearing noiselessly, not widening, or hardly at all, for weeks on end, until suddenly, when one is least expecting it, the whole slope below the crack begins to slide, carrying even forests and all else that is not firm rock down with it)"). This remark that might otherwise seem neutral becomes incredibly threatening in respect to Herr Geiser's cognitive condition. Unlike the resounding presence of rain and storms, the beginnings of the Erdrutsch (landslide) are lautlos - without a sound - and hard to detect until, suddenly and unexpectedly, the entire slope collapses. After a fissure appears, the remark continues, it can remain the same size for weeks before any change occurs. The time marker of weeks seems out of place in the sentence that refers to geologic formations that have existed for millennia, blurring the lines between Herr Geiser's condition and geologic processes. The Riß (fissure, crack), symbolizes the destructive possibility in both the natural formations around him and in his existence, which is why he feverishly examines the rock faces for cracks, using binoculars to check for changes and thereby literally changing the scale of his observation. Additionally, the abrupt end to his remarks about the fissure and the dash that signals an interruption mid-thought exemplifies the sudden changes that occur in a landslide. While examining the rock face, Herr Geiser sees "Flühe, stur wie eh und je-" (Frisch 1979, p. 46, "Walls of rock, stubborn as ever and always-"). Fluh is the Swiss-German word for rock face (Felswand) and its description as stubborn signals a state of eternal existence that stands in contrast to the following lines and the encyclopedia clippings that note how such mountains were formed. The word stur (stubborn) is usually used to refer to people (a fitting description for Herr Geiser) rather than mountains, again blurring the lines between Herr Geiser and the landscape. His stubbornness is connected to his unwillingness to admit the cracks in his memory. ${ }^{5}$

Herr Geiser sees the mountains around him not as static elements, but as elements with origins and developments in their own right. Through his careful observations, both the material history and the geologic scale of the mountains are made legible in the rock face; the layers of the rock mark the passing of time from the deep past to the present moment. After an hour of closely examining the rock face for any cracks that might foretell a rockslide, he determines that the fissures in the rocks are indeed "aus grauer Vorzeit" ("from gray, prehistoric ages") and not from the contemporary moment (Frisch 1979, p. 46). An encyclopedia clipping on "Geologische Formationen" (Geological Formations) appears in the text shortly after his examination and details how layers from fossilized plants and animals form and make up different stratigraphic strata (Frisch 1979, p. 49). The layering reveals the rock's formation and reminds Herr Geiser that, when considered through the scale of geologic time, the mountains that surround him are not static entities, reinforcing his fear of a landslide. While looking for cracks in the rock face, the highest arête of the mountain is hidden in the clouds, but Herr Geiser knows it from previous careful study: "Der Grat, der oberste, ist allerdings in Wolken; Herr Geiser kennt ihn aber auswendig: es ist ein scharfer Grat ohne Trümmer, zackig seit Jahrtausenden, Gebirge, das die Gletscher der Eiszeit überragt hat, ein zuverlässiges Gestein" (Frisch 1979, p. 47, "The ridge, the highest point, is admittedly hidden in the clouds; but Geiser knows it by heart: it is a sharp ridge free of loose debris, jagged for countless millennia, mountains that towered above the glaciers of the Ice Age, a trustworthy stone $\left.{ }^{\prime \prime}\right) .{ }^{6}$ Despite not being able to see it, Herr Geiser determines the high mountain ridge to be reliable because of the lack of debris and its existence since millennia. Again, Herr Geiser turns to signs in the material realm to confirm the passing of time. He deems the existing fissure in the rock face as non-threatening because of trees that grow in it: "Ein riesenhaften Riß in dem Fels, der hinter dem Dorf fast senkrecht in die grauen Wolken steht, ist nicht von heute oder gestern;

\footnotetext{
5 Obschlager (1992) traces the trope of the Riß throughout Frisch's work.

6 The arête provides a counter example to the "zuverlässige Steine" Herr Geiser later depends on to cross the newly formed bodies of water from the rain.
} 
es wachsen Tannen drin" (Frisch 1979, p. 46, "A huge crack in the cliff behind the village, rising almost vertically up to the gray clouds, is from neither yesterday nor today; there are fir trees growing in it"). The fissure's origins in the deep past, marked by material elements (its color and presence of trees), assures him that the crack does not pose a threat of a rockslide, while also creating a juxtaposition between the time scales of the existence of the mountain and Herr Geiser's life.

Glaciers are a central motif that further demonstrate the agency of the nonhuman world and appear as an additional threat to the village. As a nonhuman physical force, they shape the landscape by carving out features or melting to flood certain areas and represent the scale of geologic change often unnoticed by humans. The language used to describe the movements and impact of glaciers in the non-fiction clippings emphasizes their role as a lively force and presents an unembellished account of what Opperman calls storied matter or "stories embodied in material formations" (Oppermann 2016, p. 283). An encyclopedia entry on the Alps describes the dynamism of glaciers: "Die Gletscher der Eiszeit haben dieses an den Kämmen und in den Tälern gestufte Gebirge nach neuen Gesetzen umgestaltet. In oberen Enden der Täler, Schluchten, Nischen und Dolinen haben sich vielfach Kare als Wannen eingefressen und die schon zu Graten gewandelten Kämme noch mehr zugeschärft" (Frisch 1979, p. 49, "The glaciers of the Ice Age transformed these mountain ranges by acting on peaks and valleys according to new principles. Ravines, niches, sinkholes and cirques were carved out at the head of the valleys, and the peaks, already shaped into ridges, sharpened still further"). In this scientific description of glaciers shaping the landscape, the glaciers and masses of ice are clearly the primary agentic force; the subject of each sentence is a nonhuman entity. The glaciers of the ice age reshaped (umgestalten) valleys and mountains and did so "nach neuen Gesetzen" ("according to new principles"), signaling a new horizon unknown to humans. The verb einfressen (literally to eat into), moreover, emphasizes the impact of the glaciers violently piercing through the landscape. As the entry continues, it describes the material traces left by glacial movement: "Im einzelnen zeigen die [Alpen] vielerorts die allen einst vergletscherten Gebirgen eigenen Spuren der nicht nur schleifenden und polierenden, sondern auch splitternden und brechenden glazialen Erosion ... " (Frisch 1979, p. 49, "In many parts of the Alps individual mountains, all of them once covered with glaciers, reveal traces, not only of the grinding and polishing effect of glaciers, but also of erosion"). The glaciers are attributed the agency of grinding, polishing, splintering, and crushing, actions that are brought to life only through shifting the temporal scale to the deep past.

Glaciers do not only leave traces of their material forces in the past by carving out rivers and moraines, they remain as material agents of change, still slowly moving and shaping landscapes, and also melting at a much faster rate and threatening coastal regions with sea level rise. In contrast to the straightforward information provided by the reference works, Herr Geiser is unnerved about the threats posed by the geologic formations around him and his trepidation plays out in observations that are repeated in similar formulations that compound the threat. The glaciers in the area, for example, are framed as being in a process of movement: "Die Gletscher, die sich einmal bis Mailand erstreckt haben, sind überall im Rückzug ... " (Frisch 1979, p. 57, "The glaciers, which once stretched as far as Milan, are now in retreat everywhere"). A similar comment follows later: "Die Gletscher befinden sich seit Jahrhunderten im Rückzug" (Frisch 1979, p. 63, "The glaciers have been retreating for centuries"). In both remarks, the present tense emphasizes the agency of the nonhuman material entity. Their movement is not an event contained in past; it is occurring in the present and its effects extend into the future. This "potential energy" of glaciers is another threat to human life that Herr Geiser identifies repeatedly in similar formulations. Recalling glaciers in Iceland, the latent threat is described as, "Wenn das Eis der Arktis schmilzt, so ist New York unter Wasser" (Frisch 1979, p. 70, "If the Arctic ice were to melt, New York would be under water"). Later, in a list of facts that Herr Geiser focuses on to pass the time, the threat of sea level rise is mentioned again, "—wenn das Eis der Arktis schmilzt, so ist New York unter Wasser, desgleichen Europa, ausgenommen die Alpen” 
(Frisch 1979, p. 103, “-if the Arctic ice were to melt, New York would be under water, as would Europe, except for the Alps"). Finally, a hand-written note that appears as an image in the text mentions changing sea level: "Am Ende der Eiszeit lag der Meeresspiegel mindestens 100 Meter tiefer" (Frisch 1979, p. 34, "At the end of the Ice Age the level of the sea was at least 100 meters lower than today"). In all of these examples, the amount and size of ice and glaciers and the sea level are not presented as static conditions. Rather, Frisch emphasizes that the surrounding nonhuman environment is always in flux and connects sea level rise with melting glaciers, indicating the threat this poses to human life.

By framing the narrative on a geologic time scale and highlighting events of the deep past, nonhuman nature's agentic capacity becomes legible to the reader. The threat of a landslide that Herr Geiser fears is well-founded in his understanding of matter's capacity to produce change. Frisch does not frame environmental issues as a future problem. Rather, the geologic time scale means that Frisch's perspective is an expansive one, in which it is clear that all actions in the present will have a lasting effect.

\section{Materiality of the Text: "Was man mit den Zetteln machen soll?"}

The text itself is another material entity that warrants consideration. Except for the handwritten notes, all of the images come from published works like the book Frisch received from Uwe Johnson. The clippings and notes scattered throughout Der Mensch erscheint im Holozän remove conventional boundaries between fiction and non-fiction and place demands on the text in a material way. When Frisch completed the manuscript in the 1970s, he had to manually cut and paste the physical clippings onto the pages. The clippings in the text and the finite space of the physical page exhibit a narrative agency in that their size determines how much text can fit on each page. Each entry from the encyclopedia included on a page limits how much space remains for the prose text. ${ }^{7}$ Frisch provides a glimpse into how he constructed the collage of text and image within the fixed boundaries of the page in a remark about how Herr Geiser will not be able to see what is printed on the other side of the clippings that he hangs on the wall: "Was Herr Geiser nicht bedacht hat: der Text auf der Ruckseite, den Herr Geiser erst bemerkt, nachdem er die Illustrationen auf der Vorderseite sorgsam ausgeschnitten hat, wäre vielleicht nicht minder aufschlussreich gewesen; nun ist dieser Text zerstückelt, unbrauchbar für die Zettelwand" (Frisch 1979, p. 116, "Something Geiser has not taken into account: that the text on the back of the page might perhaps be no less illuminating than the picture on the front that he has so carefully cut out; now this text has been cut to pieces, useless for his gallery"). Considering the physical clippings, the same is true for Frisch as he pastes each piece of paper into the manuscript; the text on the reverse side becomes inaccessible. The parallel presented between Herr Geiser taping papers to his wall and Frisch affixing them to his manuscript establishes a tangible process that foregrounds the materiality of the text and narrative.

Völker (2016) views the arrangement of the notes as non-linear and lacking "both a clear beginning and end," but in my view, approaching the clippings as elements that produce a narrative in their own right creates a distinct account of the entanglements between humans and the environment (Völker 2016, p. 10). While the clippings interact with the text to tell one story, they also tell a story in their own right, depending on their specific arrangement. As such, the reader can follow a distinct narrative through the arrangement of the clippings. In a striking example that Crauwels (2011) points out, the encyclopedia entry on "Mensch" is featured in the exact center of the book (on page 71 of 143 , in the middle of the page). Frisch physically places humans at the center of the book in what Crauwels cleverly identifies as "wörtlicher Anthropozentrismus" (literal anthropocentrism) (Crauwels 2011, p. 117).

However, this physical arrangement is the only centering of the human that persists. Nature's likely dominance over humans is otherwise emphasized in the text, most

\footnotetext{
7 These finitudes also mirror Herr Geiser's cognitive capacity and he has to make decisions about what to include and what to take down, as in the example of the portrait of his wife that he removes. Attanucci compares the space on the wall to the finite space of a computer's hard drive or a memory stick, noting that the limits of finitude force Herr Geiser to determine what is most important (Attanucci 2016, p. 17).
} 
poignantly when Herr Geiser's clippings are effortlessly blown from the wall. Like the stratified layers of the earth's past that Herr Geiser observes on the rock face and that are detailed in the encyclopedia entry on "Geologische Formationen," the clippings he hangs on the wall become a layered, material record of both his individual life and the collective human past. Yet, unlike the expansive time scale of geologic eras, Herr Geiser's life appears fleeting and he realizes that his efforts to preserve his memory are useless: "Es gäbe noch vieles an die Wände zu kleben, wenn es nicht zwecklos wäre, weil das Klebeband, MAGIC TAPE, nichts taugt; ein Durchzug, wenn Corinne die Fensterläden öffnet, und die Zettel liegen auf dem Teppich, ein Wirrwarr, das keinen Sinn gibt" (Frisch 1979, p. 137, "There would still be many things to stick to the wall if there were any point in it; the Magic Tape is useless; a puff of air as Corinne opens the shutters and the slips of paper are lying on the floor, a confused heap that makes no sense"). The ease with which the slips of paper are blown away evoke the fragility of human memory, as well as the time span of one human life in relation to geologic history as mentioned above. Landing in a cluttered mess that mirrors Herr Geiser's cognition and confusion post-stroke, the layered record of his life and his own history, including the central entry on "Mensch," is easily blown away by another force of nature-a gust of wind.

Although these examples frame humans as relatively insignificant in the face of nonhuman nature - the comparison of humans with massive mountains and dinosaurs leaves the human looking trivial- the narrative still remains sympathetic to the human. With the different shifts of time, Frisch is able to construct a poignant commentary on the relationship between humans and their environment while not dismissing human life entirely. In other words, Herr Geiser remains a sympathetic figure to the reader while the overarching narrative expresses the insignificance of the human species on a geologic scale. Frisch succeeds in telling both human and nonhuman stories and ultimately performs one of the goals of environmental literature by decentering - but not dismissing - the human and opening up stories to a broader horizon of shared agencies beyond the human.

\section{5. “Übrigens regnet es weiter"}

Frisch's complex narrative composition of image and text discloses entanglements between humans and nonhuman entities. Through the encyclopedia clippings, Frisch reveals the impact of rain and weather systems on the human body, depicting these latent elements as powerful agents. The focus on rain further shows how seemingly small factors can cause immense changes over vast periods of time, but the agency of matter is often indiscernible on a familiar human scale. By expanding the temporal dimension of the narrative to include the deep past, Frisch displays the dynamism of matter on multiple scales.

At a few different points in the narrative, a subjective remark appears about life in the valley. It appears to be Herr Geiser's rebuttal to his late wife Elsbeth about their decision to move to the quiet town from the city of Basel: "Alles in allem kein totes Tal" (Frisch 1979, p. 60, "All in all, not a deserted valley," literally, "All in all not a dead valley"). Presumably, the comment rejects the idea that there is no excitement or cultural happenings in the small valley town. Through the lens of material ecocriticism, however, the valley can be interpreted as the actual, physical structures. In this case, the valley is certainly not dead-or lifeless, static, frozen. Rather, it is a dynamic area that emerged over hundreds of millions of years and continues to change in ways that are difficult for humans to comprehend. Through the distinct combination of different temporal scales, attention to nonhuman forces and the formal narrative elements, Frisch succeeds in his attempt "ein Tal zu erzählen" (to narrate a valley) (Frisch and Johnson 1999, p. 50).

Funding: This research received no external funding.

Institutional Review Board Statement: Not applicable.

Informed Consent Statement: Not applicable. 


\section{Data Availability Statement: Not applicable.}

Acknowledgments: I would like to thank the anonymous reviewers for their supportive and helpful comments. Thank you as well to Dan Nolan and Seth Peabody who provided feedback on an earlier version of this article. I am especially grateful for Charlotte Melin who has provided guidance on many versions of this project.

Conflicts of Interest: The author declares no conflict of interest.

\section{References}

Alaimo, Stacy. 2010. Bodily Natures: Science, Environment and the Material Self. Bloomington: Indiana University Press.

Attanucci, Timothy. 2016. Wer hat Angst vor der Geologie? Zum Schicksal Der 'geologischen Kränkung' in der Literatur des 20. Jahrhunderts Am Beispiel von Willem Frederik Hermans, Max Frisch und Peter Handke. Literatur Für Leser 39: 9-24.

Barad, Karen. 2007. Meeting the Universe Halfway: Quantum Physics and the Entanglement of Matter and Meaning. Duke: Duke University Press.

Bennett, Jane. 2010. Vibrant Matter: A Political Ecology of Things. Duke: Duke University Press.

Braungart, Georg. 2007. 'Katastrophen kennt allein der Mensch, sofern er sie überlebt': Max Frisch, Peter Handke und die Geologie. In Figurationen der literarischen Moderne. Edited by Helmuth Kiesel, Carsten Dutt and Roman Luckscheiter. Heidelberg: Winter, pp. 23-41.

Clark, Timothy. 2020. The Value of Ecocriticism. Cambridge: Cambridge University Press.

Crauwels, Geert. 2011. Über die sprachlose Sprache: Modi memoranda und Collage als Kompositionstechnik in Der Mensch erscheint im Holozän. In Max Frisch: Citoyen und Poet. Edited by Daniel de Vin. Göttingen: Wallstein, pp. 106-19.

Duckert, Lowell. 2014. When It Rains. In Material Ecocriticism. Edited by Serenella Iovino and Serpil Oppermann. Bloomington: Indiana University Press, pp. 114-29.

Duckert, Lowell. 2017. For All Waters: Finding Ourselves in Early Modern Wetscapes. Minneapolis: University of Minnesota Press.

Dürbeck, Gabriele. 2017. Climate Change Fiction and Ecothrillers in Contemporary German-Speaking Literature. In Ecological Thought in German Literature and Culture. Edited by Gabriele Dürbeck, Urte Stobbe, Hubert Zapf and Evi Zemanek. Lanham: Lexington Books, pp. 331-45.

Frisch, Max. 1979. Der Mensch erscheint im Holozän. Berlin: Suhrkamp.

Frisch, Max. 1980. Man in the Holocene. Translated by Geoffrey Skelton. New York: Harcourt Brace Janovich.

Frisch, Max, and Uwe Johnson. 1999. Der Briefwechsel. 1964-1983. Edited by Eberhard Fahlke. Berlin: Suhrkamp.

Iovino, Serenella, and Serpil Oppermann. 2012. Theorizing Material Ecocriticism: A Diptych. Interdisciplinary Studies in Literature and Environment 19: 448-75. [CrossRef]

Kilcher, Andreas B. 2011. Max Frisch: Leben, Werk, Wirkung. Berlin: Suhrkamp.

Latour, Bruno. 2005. Reassembling the Social: An Introduction to Actor-Network Theory. Oxford: Oxford University Press.

Malkmus, Bernhard. 2015. Naturgeschichten vom Fisch, oder: Die Angst vor dem Anthropozän. Scheidewege 45: 183-200.

Malkmus, Bernhard. 2017. 'Man in the Anthropocene': Max Frisch's Environmental History. PMLA 132: 71-85. [CrossRef]

Obschlager, Walter. 1992. Risse. Kleiner Versuch, einer Spur im Werk Max Frischs nachzugehen. In Leben gefällt mir-Begegnung mit Max Frisch. Edited by Daniel de Vin. Brussels: Literarische Treffpunkt, pp. 51-57.

Oppermann, Serpil. 2016. From Material to Posthuman Ecocriticism: Hybridity, Stories, Natures. In Handbook of Ecocriticism and Cultural Ecology. Edited by Hubert Zapf. Berlin: De Gruyter, pp. 273-94.

Röthinger, Julia. 2015. 'Erosion ist ein langsamer Vorgang:' das Verschwinden des Ich in Max Frischs Erzählung Der Mensch erscheint im Holozän. In Limbus: Australisches Jahrbuch für germanistische Literatur und Kulturwissenschaft, Altern/Ageing. Edited by Franz-Josef Dieters. Freiburg: Rombach Verlag, vol. 8, pp. 125-46.

Silber, Leonie. 2014. 'Die Gesteine brauchen sein Gedächtnis nicht': über die Erosion von Berg, Selbst und Erinnerung bei Max Frisch und Brigitte Kronauer. In Das Erschreiben der Berge: Die Alpen in der deutschsprachigen Literatur. Edited by Johann Georg Lughofer. Innsbruck: Innsbruck University Press, pp. 219-30.

Völker, Oliver. 2016. 'Che tempo, che tempo:' Geology and Environment in Max Frisch's Der Mensch erscheint im Holozän. On_Culture: The Open Journal for the Study of Culture 2: 2-21.

Woods, Derek. 2014. Scale Critique for the Anthropocene. The Minnesota Review 2014: 133-42. [CrossRef] 